\title{
A false occult hepatitis $B$ virus infection developed in a patient with psoriatic arthritis under infliximab and methotrexate therapy
}

\author{
A. Notarnicola'1, F. lannone', G. Lopalco', M. Covelli ${ }^{2}$, G. Lapadula ${ }^{1}$ \\ ${ }^{1}$ Department of Medicine, Medical School, University of Bari; \\ ${ }^{2}$ Rheumatology Unit, Medical School, University of Bari, Italy
}

\begin{abstract}
SUMMARY
Despite lacking of international guidelines about the management of patients with occult hepatitis B virus infection (OBI) starting TNF- $\alpha$ blockers, there is some evidence from real life settings that these drugs are safe in OBI patients with rheumatic diseases. On the contrary, the management of the so-called false OBI patients appears still undefined. We describe a case of acute hepatitis B virus (HBV) infection occurred in an anti-HBs and anti$\mathrm{HBc}$ positive patient affected by psoriatic arthritis, who had been treated for five years with infliximab. Baseline HBV-DNA analysis had not been performed. Although HBs Ag was still negative and the transaminases in the normal range, HBV-DNA serum analysis surprisingly showed high replication rate. Entecavir was added, and three months later HBV-DNA was no longer detectable. Even if $\mathrm{HBs} \mathrm{Ag}$ is persistently negative, the assessment of HBV-DNA should be recommended at least at baseline in order to rule out hidden active necro-inflammatory liver disease.
\end{abstract}

Key words: false occult hepatitis B infection, anti-TNF- $\alpha$, rheumatic diseases, HBV-DNA by real-time PCR.

Reumatismo, 2013; 65 (6): 298-301

\section{INTRODUCTION}

Worldwide, hepatitis $\mathrm{B}$ virus infection (HBV) affects among 2 billion people and it is one of the major causes of liver related morbidity and mortality. All over the world, 350 million people are chronically infected (1). The large reservoir of HBV chronic carriers can be split into three groups:

1) active carriers who are positive for $\mathrm{HB}$ surface antigen ( $\mathrm{HBs} \mathrm{Ag}$ ), $\mathrm{HBe} \mathrm{Ag}$ or antibodies against $\mathrm{HBe} \mathrm{Ag}$ (anti-HBe $\mathrm{Ag}$ ) and the serum viral load is more than $20,000 \mathrm{UI} / \mathrm{mL}$;

2) inactive carriers who are positive for $\mathrm{HBs} \mathrm{Ag}$, anti-HBe $\mathrm{Ag}$ and serum HBVDNA is less than $20.000 \mathrm{UI} / \mathrm{mL}$;

3) occult HBV carriers who test negative for HBs Ag but positive for detection of anti hepatitis B core (anti-HBc).

Corresponding autho: Antonella Notarnicola MD Research Assistant of Rheumatology Department of Medicine Rheumatology Unit, Policlinico Piazza G. Cesare, 11 - 70124 Bari, Italy E-mail: notarnicola.antonella@gmail.com
Serum anti-HBc levels are considered the serological marker of occult HBV infection $(\mathrm{OBI})$ which is characterized by closed circular DNA within the hepatocytes and very low levels of serum HBV $(<200 \mathrm{IU} /$
$\mathrm{mL})(2,3)$. Even if the HBV panel including $\mathrm{HBs} \mathrm{Ag}, \mathrm{HBe} \mathrm{Ag}$, anti-HBs $\mathrm{Ag}$, anti$\mathrm{HBc}, \mathrm{HBe} \mathrm{Ag}$, anti-HBe Ag allows to address the correct diagnosis among the three categories, only the analysis of HBV-DNA by real-time PCR discriminate between the overt and the occult HBV infection (4). The chronic HBV carrier, especially in immunosuppressive conditions, can experience the phenomenon of reactivation of HBV replication that occurs in three different ways according to the virological categories: in active carriers, the persistence of a significant viremia is frequently associated with progression of liver damage (reaxacerbation); in inactive carriers, the increase of a significant viremia $(\geq 20,000$ $\mathrm{IU} / \mathrm{mL}$ ) causes liver damage (reactivation); in occult carriers, the reemergence of HBsAg (sero-reversion) usually announces that HBV replication has just restarted (5). Unfortunately, with regard of the OBI carriers, HBV infection can also occur without the warning of the sero-reversion and the phenomenon is called false OBI. The false OBI is defined by the presence 
of very high level of serum HBV-DNA, although HBs Ag is always undetectable, and it is due to mutations in the immunodominant region of $\mathrm{HBs} \mathrm{Ag}$ which are not recognized by commercially detection assays (6).

As a major concern in the era of biologic therapy, rheumatologists have been worrying about the possibility of HBV reactivation in patients receiving monoclonal antibodies such as rituximab (anti CD-20) or TNF-alpha antagonists.

Both TNF-alpha and B cells play a key role in stopping viral replication, hence their antagonists could lead the immune system to discontinue the strong suppression of virus replication (5).

\section{CASE REPORT}

We report the case of a 49-year old Caucasian, male patient, affected by peripheral psoriatic arthritis who was referred to our center for the first time on December 2010. He was treated since December 2005 with Infliximab $5 \mathrm{mg} / \mathrm{kg}$ every eight weeks plus Methotrexate $5 \mathrm{mg}$ a week plus methylprednisolone $4 \mathrm{mg}$ daily in another hospital. The HBV panel at the beginning of therapy (December 2005) showed only the presence of anti-HBs and anti-HBc in the blood serum while HBV-DNA serum PCR analysis had not been performed.

Before continuing infliximab in our center, HBV serology was re-checked, confirming that anti-HBs $\mathrm{Ag}$ and anti-HBc were positive, whereas $\mathrm{HBs} \mathrm{Ag}, \mathrm{HBe} \mathrm{Ag}$, anti-HBe $\mathrm{Ag}$ and the antibodies against hepatitis $\mathrm{C}$ virus $(\mathrm{HCV})$ were negative. In addition, the aspartate aminotransferase (AST) and the alanine aminotransferase (ALT) levels were slightly elevated, 41 U/I (n.v. 5-37) and 62 U/I (n.v. 5-41), respectively. Liver ultrasonography showed normal findings. Since HBV status was not changed, infliximab therapy was approved and the assessment of HBs Ag, anti-HBs Ag and liver enzymes was ordered every three months. Three months later, during biologic treatment, HBs Ag was still negative, the antiHBs Ag titers increased and the liver en- zyme levels normalized. On June 2011, even if no clinical and laboratory signs of infection were present, HBV-DNA analysis by real-time PCR surprisingly showed a very high replication rate o $85554 \mathrm{U} / \mathrm{mL}$. Infliximab and methotrexate were stopped and entecavir $0.5 \mathrm{mg}$ a day was prescribed. Unfortunately, the patient experienced a flare of the arthritis involving both wrists and knees and, after one month, he restarted therapy with infliximab and methotrexate in combination with entecavir $0.5 \mathrm{mg}$ a day.

On September 2011, HBV-DNA was not longer detectable in the blood serum. The treatment protocol was not changed and the patient, with currently arthritis remission, is still under tight follow-up.

\section{DISCUSSION}

International guidelines dealing with the management of HBV reactivation occurring in patients with rheumatic diseases undergoing anti TNF- $\alpha$ therapy, especially in those with OBI, are still lacking (7). It is widely accepted that patients affected by rheumatic diseases before starting biological agents should be screened for HBV and HCV and the baseline HBV assessment should include HBs Ag, anti-HBs, anti-HBc, AST, ALT and HBV-DNA assay by real time PCR (7).

According to European Association for the study of the liver (EASL) guidelines (8, 9), it is known that $\mathrm{HBV}$ reactivation can occur either in $\mathrm{HBs} \mathrm{Ag}$ positive patients (active or inactive carriers) or in $\mathrm{HBs} \mathrm{Ag}$ negative/anti-HBc positive patients, especially during or after the immunosuppressive treatment. In active carriers, antiviral therapy (entecavir/tenofovir) should be started 1-2 weeks before biological treatment and should be provided for at least 12 months after the biological treatment has been interrupted; in inactive carriers, prophylaxis with lamivudine should be recommended and provided for at least further 6 months after the biological therapy has been stopped; in patients affected by OBI, it should be enough to monitor at 
least every 3 months HBs Ag, anti-HBs Ag, AST and ALT levels. Supporting the idea of the safety of TNF- $\alpha$ blockade in anti$H B c$ alone carriers (true $\mathrm{OBI}$ ), a prospective study involving a large series of $\mathrm{HBs}$ Ag-negative, anti-HBc-positive patients followed for $>3$ years during anti TNF- $\alpha$ treatment not combined with lamivudine showed no signs of viral reactivation (10). For the OBI carriers, the decline of the HBs-Ab levels represents a warning of possible viral reactivation and it generally anticipates the sero-reversion that is the reappearance of $\mathrm{HBs} \mathrm{Ag}$. If $\mathrm{HBs} \mathrm{Ab}$ titer starts to decrease or AST and ALT levels to increase, HBV-DNA should be tested again (11).

However, our case report shows that HBV replication can also occur even if the sero-reversion and the decrease of HBs $\mathrm{Ab}$ have never happened. This phenomenon is called false OBI and it is due to HBV with $\mathrm{S}$ gene mutations which are not detected by available commercial assays. It is not exactly known which is the prevalence of false occult HBV infection among OBI patients and, to date, few case reports involving rheumatic patients have been already published (12-15). Regarding our case report, if HBV-DNA analysis by real-time PCR had been performed before starting Infliximab, the patient would have been considered as an active carrier from the beginning, deserving more effective antiviral drugs.

Therefore, despite of the absence of clinical or laboratory signs of HBV infection, the HBV-DNA detection may be considered the only useful tool to figure out the right diagnosis.

In conclusion, although recommendations about the correct timing for the assessment of HBV-DNA are still not available for OBI patients with rheumatic diseases undergoing biologic agents, our experience from real life settings suggests that HBVDNA serum level should be performed al least at the beginning of immunosuppressive therapy and according to anti-HBs $\mathrm{Ag}, \mathrm{AST}$ and ALT levels variation, in order to avoid the sudden reappearance of active necro-inflammatory liver disease.

\section{KEY MESSAGES}

- The false occult hepatitis B virus infection is defined by the presence of very high levels of serum HBV-DNA, even if $\mathrm{HBs} \mathrm{Ag}$ is always undetectable;

- HBV-DNA analysis by real-time PCR is the only test useful to discriminate between active or occult HBV infection;

- International guidelines on the management of HBV reactivation in rheumatic patients undergoing biologic agents are still lacking.

\section{REFERENCES}

1. Ott JJ, Stevens GA, Groeger J, Wiersma ST. Global epidemiology of hepatitis B virus infection: new estimates of age-specific HBsAg seroprevalence and endemicity. Vaccine. 2012; 30: 2212-9.

2. McMahon BJ. The natural history of chronic hepatitis B virus infection. Hepatology. 2009; 49: S45-55.

3. Marzano A, Angelucci E, Andreone P, Brunetto M, Bruno R, Burra P, et al. Prophylaxis and treatment of hepatitis $\mathrm{B}$ in immunocompromised patients. Dig Liver Dis. 2007; 39: 397-408.

4. Mangia A, Antonucci F, Brunetto M, Capobianchi M, Fagiuoli S, Guido M, et al. The use of molecular assays in the management of viral hepatitis. Dig Liver Dis. 2008; 40: 395 404.

5. Mastroianni CM, Lichtner M, Citton R, Del BC, Rago A, Martini H, et al. Current trends in management of hepatitis $\mathrm{B}$ virus reactivation in the biologic therapy era. World J Gastroenterol. 2011; 17: 3881-7.

6. Launay O, Masurel J, Servant-Delmas A, Basse-Guerineau AL, Meritet JF, Laperche S, et al. High levels of serum hepatitis B virus DNA in patients with 'anti-HBc alone': role of HBsAg mutants. J Viral Hepat. 2011; 18 : 721-9.

7. Furst DE, Keystone EC, So AK, Braun J, Breedveld FC, Burmester GR, et al. Updated consensus statement on biological agents for the treatment of rheumatic diseases, 2012. Ann Rheum Dis. 2013; 72: ii2-34.

8. Zhuang H. [Updates of EASL clinical practice guidelines: management of chronic hepatitis B virus infection]. Zhonghua Gan Zang Bing Za Zhi. 2012; 20: 427-9.

9. EASL clinical practice guidelines: Management of chronic hepatitis B virus infection. J Hepatol. 2012; 57: 167-85.

10. Caporali R, Bobbio-Pallavicini F, Atzeni F, 
Sakellariou G, Caprioli M, Montecucco C, et al. Safety of tumor necrosis factor alpha blockers in hepatitis B virus occult carriers (hepatitis B surface antigen negative/anti-hepatitis B core antigen positive) with rheumatic diseases. Arthritis Care Res (Hoboken). 2010; 62: 749-54.

11. Marzano A. Management of HBV infection during immunosuppressive treatment. Mediterr J Hematol Infect Dis. 2009; 1(3):e2009025.

12. Bazhenov AI, Konopleva MV, El'gort DA, Fel'dsherova AA, Budnitskaia PZ, Nikitina NI, et al. [Algorithm of serologic screening and assessment of prevalence of serologically meaningful mutations of HBsAg in hepatitis B virus carriers]. Zh Mikrobiol Epidemiol Immunobiol. 2007; 6: 30-7.
13. Roche B, Roque-Afonso AM, Sebagh M, Delvart V, Duclos-Vallee JC, Castaing D, et al. Escape hepatitis $\mathrm{B}$ virus mutations in recipients of antibody to hepatitis B core antigenpositive liver grafts receiving hepatitis B immunoglobulins. Liver Transpl. 2010; 16: 88594.

14. Roque-Afonso AM, Ferey MP, Belkhiri D, Dussaix E. [HBs antigen mutants: prevalence, clinical and diagnostic implications]. Pathol Biol (Paris). 2005; 53: 563-8.

15. Ito S, Nakazono K, Murasawa A, Mita Y, Hata K, Saito N, et al. Development of fulminant hepatitis B (precore variant mutant type) after the discontinuation of low-dose methotrexate therapy in a rheumatoid arthritis patient. Arthritis Rheum. 2001; 44: 339-42. 